\title{
VARK LEARNING STYLES TOWARDS ACADEMIC PERFORMANCE AMONG STUDENTS OF PRIVATE UNIVERSITY IN SELANGOR
}

\author{
Noor Nasyikin Md Zain ${ }^{1}$ \\ Faculty of Business \& Accountancy, Universiti Selangor, Malaysia. \\ (Email: nasyikin@unisel.edu.my) \\ Fazilah Tamsir ${ }^{2}$ \\ Faculty of Business \& Accountancy, Universiti Selangor, Malaysia. \\ (Email: fazilah@unisel.edu.my) \\ Noor Ayuernie Ibrahim ${ }^{3}$ \\ Faculty of Business \& Accountancy, Universiti Selangor, Malaysia. \\ (Email: noor_ayuernie@yahoo.com) \\ Halimi Poniran ${ }^{4}$ \\ Faculty of Business \& Accountancy, Universiti Selangor, Malaysia. \\ (Email: halimi@unisel.edu.my) \\ Amirul Syafiq Mohd Ghazali ${ }^{5}$ \\ Faculty of Business \& Accountancy, Universiti Selangor, Malaysia. \\ (Email: amirul@unisel.edu.my)
}

Received date: $15-10-2019$

Revised date: 15-10-2019

Accepted date: 17-10-2019

Published date: 12-12-2019

To cite this document: Md. Zain, N. A., Tamsir, F., Ibrahim, N. A., Poniran, H., \& Mohd Ghazali, A. S. (2019). VARK Learning Styles Towards Academic Performance Among Students Of Private University In Selangor. International Journal of Modern Trends in Social Sciences, 2(10), 01-12.

DOI: $10.35631 / \mathrm{IJMTSS} .210001$

Abstract: The objectives of this study are twofold: (a) to examine the influence of students' learning styles on their academic performance; and $(b)$ to identifies the preferred learning styles of students between high/low achievers, gender, and different clusters. By using VARK standard questionnaire, 433 undergraduate students from four faculties at the Private University in Selangor are used as observations for this study. The study finds that all students were unimodal learners and Kinesthetic $(K)$ type of learning style is the learner type with the most number of students. High achievers are preferred Kinesthetic $(K)$ learning style while Read/Write $(R)$ learning style is more practiced by students with low achievement. Male students are more preferred Kinesthetic $(K)$ learning style, but female students had a preference for Visual (V) learning style. Social science students are more preferred an Aural (A) as compared to the pure science students which are more preferred Read/Write $(R)$ learning style. Further, this study confirms that Visual $(V)$ and Kinesthetic $(K)$ learning style preferences are positively and significantly influence students' academic performance. This indicates that different subjects required different kinds of learning styles and instructions to optimally potentiate and benefit the students. This result is consistent with the "Meshing 
Hypothesis" which states that the learning outcomes could be highly achieved if learning was matched with a predominant learning style of the learner. This study gives a better representation of the current situation in the learning preferences among undergraduate students in Malaysia.

Keywords: Learning Style, VARK Instrument, Academic Performance, Private University

\section{Introduction}

Students' learning styles and academic performance are interesting topic to discuss among academicians and psychologists. According to Romanelli et al. (2009), learning styles are considered by many to be one factor of success in higher education. In general, a learning style generally refers denotes to a person's preferred way of learning (Marriott, 2002), and the methods of learning of students are which is often associated with their one's learning performances and is therefore seen as considered to predict a predictor of academic success. Each student learns in different ways and this affects their performance. Students and teachers must update themselves and find appropriate ways for learning (Samarakoon et al., 2013). In such situations learning styles can help them improve their learning ability (Nuzhat et al., 2013). Identifying learning styles of students is important and is sometimes considered to be a teacher's responsibility (Shenoy \& Shenoy, 2013). Lecturers must adopt themselves with learning styles of students In order to achieve maximize students' performance (Kharb et al., 2013).

In Malaysia, students are not spared from the advancement of technology, therefore their learning preferences had also changed with time along due to this advancement. Many higher institutions already have adopted information technology as one of their platforms for student learning and assessments (Ao, 2014; Chun, 2014). However, due to advancement of technology that traditional higher education is not structured to provide this balance, severe mismatches commonly occur between the teaching styles of instructors and the learning styles of their students (Felder et al., 2012). Bertolami (2001) has proposed that one reason for students' frustration towards the curriculum is inconsistency between learning content and instructor's teaching methods. These mismatches may lead to negative effects on the academic performance quality of the students and on their attitudes toward their education (Prasad et al., 2017). On the other hand, the quality of students' thoughts is critical to learning and could potentially determine their academic achievement. If the students' learning style is matched with the teaching styles of instructors, then why some students obtained good results in their study, but others are not?

Research on students learning styles has shown that preferences of these learning styles also differ across different streams and courses from engineering to sciences, to humanities, architecture, pharmacy, and health sciences (Bakon et al., 2016; Demirkan, 2016). However, little is understood about how learning styles impact performance across different courses in higher learning institution. Apart from learners' course, the preference of learning styles can also relate to gender. Results from earlier reports have revealed a possible effect of gender on learning styles (Demirbas \& Demirkan, 2007). Similarly, Brew (2002) found that learning style is sensitive to gender and the validity of learning style instrument score varies for females and males. In the context of Malaysian Higher Learning Institution (HEI), a question arises as does male and female are differing in their learning style? Are students in different courses are differs in their learning style? 
With a variety of learning aids available these days, there is need to identify the most efficient way to match and deliver the teaching and learning instructions to help the students to become more capable learners. Fleming and Mills (1992) designed a questionnaire called as the Visual (V), Aural (A), Read/Write (R), and Kinesthetic (K) (VARK) questionnaire to determine a preferred method of learning. The VARK instrument defined the learning preference based on the sensory modality in which a student prefers to take in new information (Fleming, 2015). The VARK questionnaire is a simple and easy to administer tool that encourages students to describe their learning behavior (Cavanagh \& Coffin, 1994; Sandmire et al., 2000). Therefore, this study decided to focus on the identification of students' their learning styles using VARK questionnaire. The aim of this study is to identify the preferred learning style of high/low achiever students, different gender, and clusters. Besides, this study also intent to examine the relationship between students' learning styles and their academic performance.

\section{Literature Review}

Learning style can be defined as the manner in which and the conditions under which learners most efficiently and effectively perceive, process, store, and recall what they are attempting to learn (James \& Gardner, 1995). Further, Reid (1995) defined learning style as an individual's natural, habitual, and preferred way of absorbing, processing, and retaining new information and skills. While Felder and Spurlin (2005) defined learning styles as the diverse ways students take in and process data. Another popular definition for learning styles refers to individuals' characteristics and preferred ways of gathering, organizing, and thinking about information (Fleming, 2005).

The relationship between learning styles and academic performance in educational sector has been extensively studied but remains inconclusive. Some studies point out that there is no effect of learning styles on academic performance (Alghasham, 2012; Tariq et al., 2016). On the other hand, other studies have demonstrated differences between the academic performances of students with different learning styles. Al-Saud (2013) demonstrated that there is a relationship between the learning styles and academic performances of the undergraduate students. Similarly, Hur and Kim (2017) showed that Korean medical students with a reflective learning style preference performed significantly better in participation, problem solving, quiz, and team work. Furthermore, there is scientific evidence that students with intuitive learning preferences perform significantly better than students with sensing preferences in basic science, general pathology, and clinical pathology courses (Demirkan, 2016). Regards to VARK learning style preference, Dobson (2010) found that a solid Kinesthetic (K) learning style had a significant positive relationship with performance in physiology courses among a sample of 64 students.

Studies analyzing gender differences in learning styles of undergraduate students have yielded contradictory results. On the one hand, there is empirical evidence that gender has a significant influence on learning styles (Almigbal, 2015; Raja \& Priyadharsini, 2018). For example, Hosford and Siders (2010) found that a significantly higher number of female medical students preferred the sensing mode of learning as compared to males; whereas a significant number of male medical students preferred the visual mode. In addition, there seems to be research evidence that females prefer to learn by trying things (i.e., active learning style) rather than by thinking things through (i.e., reflective learning style) (Tariq et al., 2016). Other related research showed that male students preferred to use the kinesthetic learning style more than females, while female students preferred the aural learning style (Sarabi-Asiabar et al., 2015).

There is a lot of evidence that students from different fields of study often demonstrate different preferences in their learning styles (Derkach \& Starova, 2017; Yaroshenko \& Derkach, 2012). 
The nature of the emergence of different learning styles in different fields of study is not finally evident yet. There are a number of studies that have examined the relationship between learning style and academic performance in various fields of studies. Previous research on students learning styles has shown that preferences of these learning styles also differ across different streams and courses from engineering to sciences to humanities, architecture, pharmacy and health sciences (Bakon et al., 2016; Demirkan, 2016). The body of knowledge, end objectives of each of these courses, the teaching strategies, and environment all play a part in shaping and reinforcing the learning strategy preferences of different groups of students (Samarakoon et al., 2013).

Based on these discussions, understanding the type of preferred learning styles enables teachers of different specialties to design course materials so that they can be equally well-learned by all students. Recognising their own methods of study helps students to master the disciplines by developing a strategy of activity in accordance with their preferences, providing a basis for mastering new patterns of behavior (Wilson \& Narayan, 2014).

\section{Research Methodology}

Matching students' learning styles with a learning framework has resulted in improved academic performance scores, whereas a mismatch between learning styles and curriculum has led to low levels of academic achievement (Aripin et al., 2008). To become effective teachers, educators should understand a learner's characteristics and their learning style (Choudhary et al., 2011). However, there are still a number of important issues that have yet to be established, including the relationship between learning styles and academic achievement (Dobson, 2010). The literature concerning the relationship between learning style preferences and academic achievement contains conflicting results.

Based on the views presented in the literature reviews section, Figure 1 shows the research framework for this study. This study conjectures that the students' learning style preference can be assessed from the point of its impact on the students' academic performance. Hence, this study proposes that there is an influence between learning styles (Visual, Aural, Read/Write, and Kinesthetic) towards the students' academic performance (dependent variable).

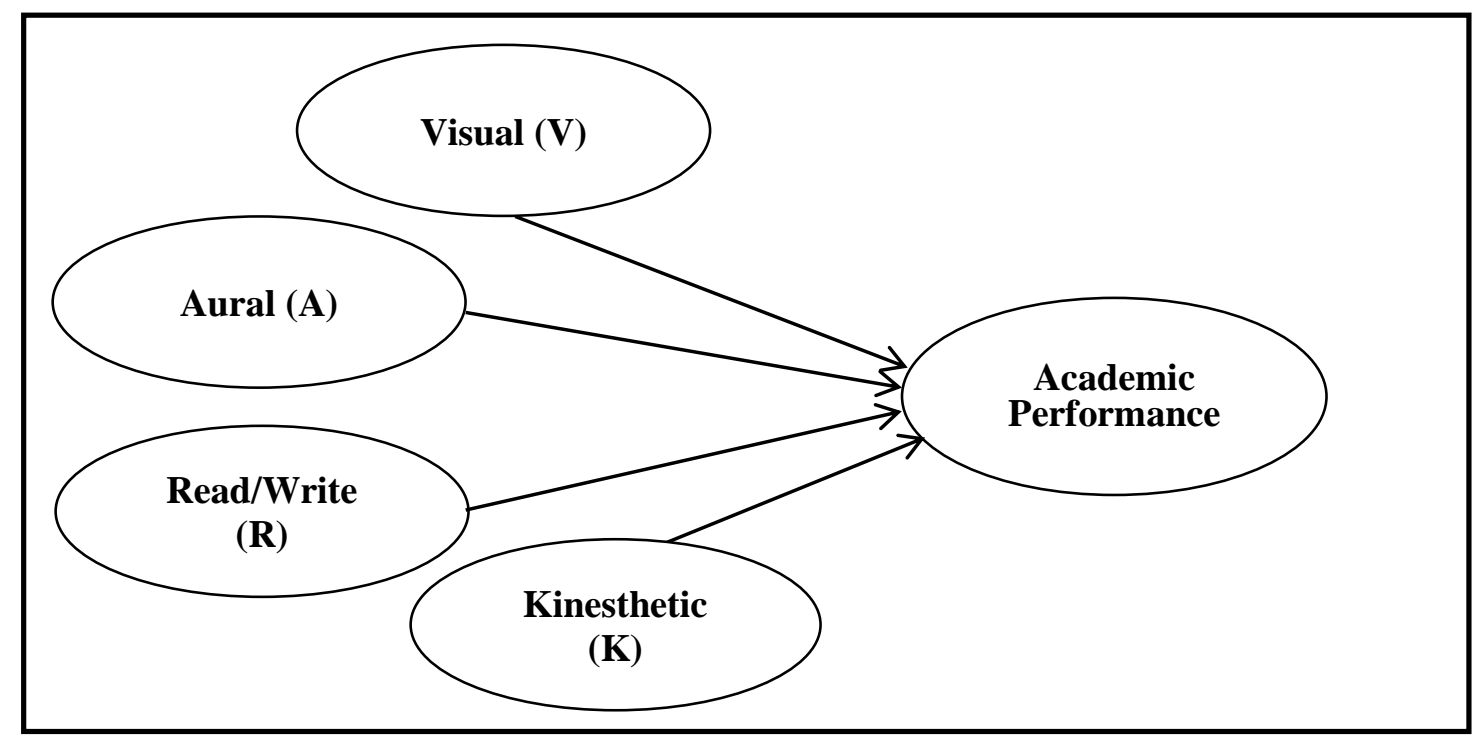

Figure 1: Conceptual Framework 


\section{Data Collection Procedure}

The sampling frame of this study will be several faculties at the Private University in Selangor. Specifically, this research was carried out in four faculties namely as Faculty of Communication, Visual Arts and Computing, Faculty of Engineering and Life Sciences, Faculty of Educations and Social Sciences, and Faculty of Business and Accountancy. This research's population is the undergraduate students in the respective faculties. As at $31^{\text {st }}$ December 2018, there are a total of 8,437 undergraduate students in these four faculties. This study follows decision model table proposed by Krejcie and Morgan (1970) to determine the necessary sample size because their sample decision model is claimed to be able to provide a good sample size decision. Since the population of undergraduate students in these four faculties are 8,437 students, this research needs at least 368 respondents to initiate the indicatives of sample for generalisability of this research. The cluster sampling method is used in deciding the number of samples from each faculty.

The dependent variable is performance scores (grades) of the students which is measure using Cumulative Grade Point Average (CGPA). On the other hand, the independent variable is learning style that is measure using VARK instrument. The latest English version of the VARK questionnaire was used in this study which is VARK 7.1 (Fleming, 2007). The preference of Visual (V) includes the depiction of information in charts, graphs, flow charts, and all the symbolic arrows, circles, and hierarchies. Aural/Auditory (A) describes a preference for information that is "heard", while Read/Write (R) This preference is for information displayed as words. Finally, Kinesthetic $(\mathrm{K})$ refers to the "perceptual preference related to the use of experience and practice (simulated or real)." This VARK questionnaire was selected because it is reliable, concise, and easy to complete. It has also been used extensively among undergraduate students in many studies and countries. It consists of 16 questions with 4 options each. Students were allowed to choose multiple answers per item to adequately describe their preferred response(s) to the situation. Using factor analysis techniques, the reliability and validity of the VARK questionnaire was confirmed to be satisfactory (Leite et al., 2010).

\section{Results and Discussion}

Table 1 reports that the respondents in this study is dominated by female (66.7\%) compared to male (33.3\%). Respondents also were categorised into two different age groups distribution. Majority of the respondents involved in this study were in the group of age below than 25 years old. Besides, there are only 33 respondents $(7.6 \%)$ were at the age in between 25 and 34 years old. Table 1 also shows that the respondents participate in this study came from various faculties. Majority of respondents are undergraduate students from the Faculty of Business and Accountancy (67.2\%), followed by Faculty of Engineering and Life Sciences (14.3\%). There are around $10.6 \%$ participation from the Faculty of Communication, Visual Arts and Computing. Finally, the least participation is from Faculty of Educations and Social Sciences $(7.9 \%)$.

Table 1: Respondent's Profile

\begin{tabular}{llcc}
\hline Profile & Characteristics & Frequency & $\begin{array}{c}\text { Percentage } \\
(\mathbf{\%})\end{array}$ \\
\hline Gender & Male & 144 & 33.3 \\
& Female & 289 & 66.7 \\
\hline Age Group & Under 25 years & 400 & 92.4 \\
& 25 -34 years & 33 & 7.6 \\
\hline Faculty & Faculty of Business \& Accountancy & 291 & 67.2
\end{tabular}




\section{Learning Styles of Students}

Using the results of the VARK questionnaire, the distribution of the students according to the four learning styles was determined. The distribution of each group according to the learning styles is depicted in Figure 2. The figure shows that all undergraduate students at the public university in Selangor preferred a single sensory modality of learning. Among the unimodal learners, a majority, nearly 131 students $(30.3 \%)$ preferred Kinesthetic (K) type learners followed by $28.4 \%$ of Visual (V) learners $(n=123)$. Further, this study reveals that there are 121 undergraduate students $(27.9 \%)$ preferred Aural (A) learning style. Finally, the least preferred learning style is Read/Write $(\mathrm{R})$ with only $13.4 \%(\mathrm{n}=58)$ of learners.

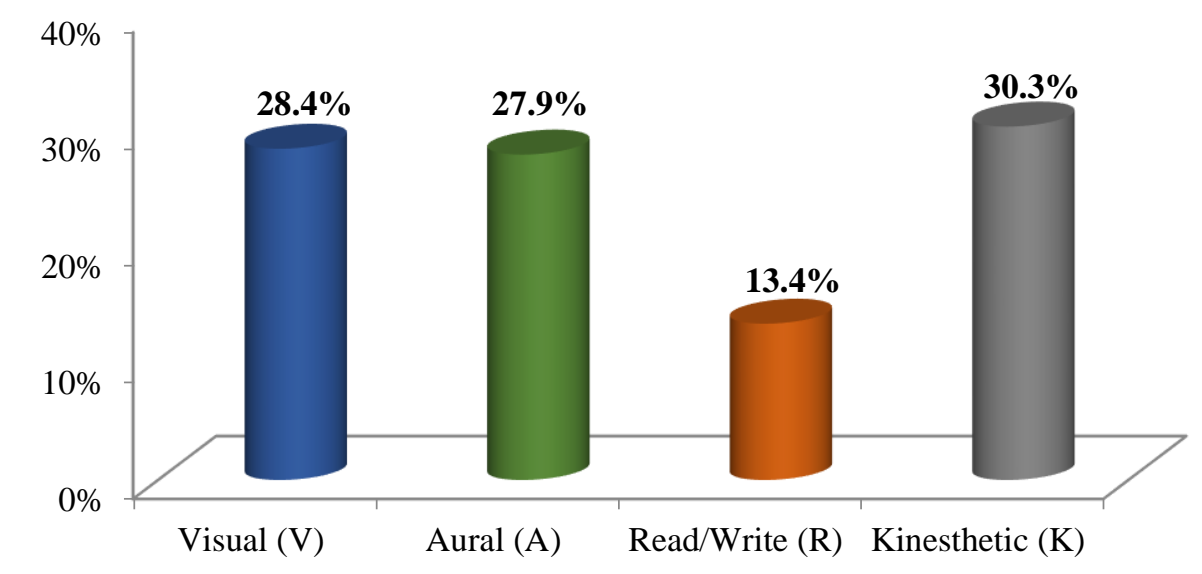

Figure 2: Distribution of Respondents According to Learning Style

\section{Learning Styles based on High/Low Achiever, Gender, and Clusters}

This section reports and discusses the findings of the study which relate to the first research objective, which is to identify the preferred learning style of high/low achiever students, different gender, and clusters. Table 2 reveals a crosstabulation of learning style preferred by undergraduate students according to their achievement. The results indicate that majority of the respondents of high achievers are preferred Kinesthetic (K) learning style $(68.7 \%)$, followed by Visual (V) learning style $(66.7 \%)$. This result is consistent with a finding by Liew et al. (2015) whereby they found that among the middle and high achievers in summative examinations, a majority had Kinesthetic (K) learning style (80.5\%). 
Table 2: Crosstabulation of Preferred Learning Style according to High and Low Achiever Students

\begin{tabular}{|c|c|c|c|c|c|}
\hline \multirow{3}{*}{ Learning Style } & \multicolumn{3}{|c|}{ Achievers } & \multirow{3}{*}{ Total } & \multirow{3}{*}{$\begin{array}{c}\text { Pearson } \\
\text { Chi-Square }\end{array}$} \\
\hline & \multirow{2}{*}{$\begin{array}{c}\begin{array}{c}\text { Low } \\
\text { Achiever }\end{array} \\
\text { n (\%) }\end{array}$} & \multirow{2}{*}{$\begin{array}{c}\begin{array}{c}\text { Average } \\
\text { Achiever }\end{array} \\
\mathbf{n}(\%)\end{array}$} & \multirow{2}{*}{$\begin{array}{c}\begin{array}{c}\text { High } \\
\text { Achiever }\end{array} \\
\text { n (\%) } \\
\end{array}$} & & \\
\hline & & & & & \\
\hline Visual (V) & $14(11.4 \%)$ & $27(22.0 \%)$ & $82(66.7 \%)$ & 123 & \\
\hline Aural (A) & $14(11.6 \%)$ & $31(25.6 \%)$ & $76(62.8 \%)$ & 121 & $3115^{\mathrm{ns}}$ \\
\hline Read/Write (R) & $10(17.2 \%)$ & $11(19.0 \%)$ & $37(63.8 \%)$ & 58 & $0.11 J$ \\
\hline Kinesthetic (K) & $16(12.2 \%)$ & $25(19.1 \%)$ & $90(68.7 \%)$ & 131 & \\
\hline Total & 54 & 94 & 285 & 433 & \\
\hline
\end{tabular}

Note: Pearson Chi-square is significant at ${ }^{* * *} 1 \%$ level, $^{* *} 5 \%$ level and ${ }^{*} 10 \%$ level, respectively, using twotailed tests.

On the other hand, respondents who are preferred Read/Write (R) learning style tend to get low achievement (17.2\%). When comparing the VARK subscale scores of high and low achiever undergraduate students at the private university, the Pearson Chi-Square test result shows that there is no significant difference in the preferred learning style between high achiever students and low achiever students.

Figure 3 depicts the pattern of gender differences among the different modes of learning style. The results show that the female students had a higher preference for Visual (V) learning style (70.7\%) while the male students preferred Kinesthetic (K) learning style (35.9\%). This result is in tandem with evidence by Sarabi-Asiabar et al. (2015) whereby they found that male students preferred to use the Kinesthetic (K) learning style more than females, while female students preferred the Aural (A) learning style. However, the Pearson Chi-Square test result in the Figure 3 shows that there is no significant difference in the preferred learning style between male and female students. This result is similar to several studies that found there is no significant gender difference in learning approach (e.g., Heikkilä \& Lonka, 2006; May et al., 2012; Richardson, 2013).

Table 3: Crosstabulation of Preferred Learning Style according to Gender

\begin{tabular}{lcccc}
\hline \multirow{2}{*}{ Learning Style } & \multicolumn{2}{c}{ Gender } & \multirow{2}{*}{ Total } & $\begin{array}{c}\text { Pearson } \\
\text { Chi-Square }\end{array}$ \\
\cline { 2 - 3 } & Male & Female & & \\
\cline { 2 - 3 } & $\mathbf{n}(\boldsymbol{\%})$ & $\mathbf{n}(\mathbf{\%})$ & & \\
\hline Visual (V) & $36(29.3 \%)$ & $\mathbf{8 7 0 . 7 \% )}$ & 123 & \\
Aural (A) & $43(35.5 \%)$ & $78(64.5 \%)$ & 121 & \multirow{2}{*}{$8.353^{\mathrm{ns}}$} \\
Read/Write (R) & $18(31.0 \%)$ & $40(69.0 \%)$ & 58 & \\
Kinesthetic (K) & $\mathbf{4 7 ( 3 5 . 9 \% )}$ & $84(64.1 \%)$ & 131 & \\
\hline Total & $\mathbf{1 4 4}$ & $\mathbf{2 8 9}$ & $\mathbf{4 3 3}$ & \\
\hline
\end{tabular}

Note: Pearson Chi-square is significant at ${ }^{* * *} 1 \%$ level, ${ }^{* *} 5 \%$ level and ${ }^{*} 10 \%$ level, respectively, using twotailed tests.

In order to assess the preferred learning styles of respondents based on cluster, the undergraduate students are grouped into two clusters, namely as pure science and social science clusters. Table 4 shows that majority of the students in social science cluster preferred an Aural 
(A) learning style (92.6\%). Contrary, students in pure science cluster are more preferred $\mathrm{Read} /$ Write (R) learning style.

Table 4: Crosstabulation of Preferred Learning Style according to Clusters

\begin{tabular}{|c|c|c|c|c|}
\hline \multirow{3}{*}{ Learning Style } & \multicolumn{2}{|c|}{ Clusters } & \multirow{3}{*}{ Total } & \multirow{3}{*}{$\begin{array}{c}\text { Pearson } \\
\text { Chi-Square }\end{array}$} \\
\hline & Social Science & Pure Science & & \\
\hline & n (\%) & n (\%) & & \\
\hline Visual (V) & $106(86.2 \%)$ & $17(13.8 \%)$ & 123 & \multirow{4}{*}{$13.112^{* * *}$} \\
\hline Aural (A) & $112(92.6 \%)$ & $9(7.4 \%)$ & 121 & \\
\hline Read/Write (R) & $42(72.4 \%)$ & $16(27.6 \%)$ & 58 & \\
\hline Kinesthetic (K) & $111(84.7 \%)$ & $20(15.3 \%)$ & 131 & \\
\hline Total & 371 & 62 & 433 & \\
\hline
\end{tabular}

Further, the result of Pearson Chi-Square test in Table 4 shows that there is a significant difference in the preferred learning style between pure science and social science clusters students. This result suggests that preferences of learning styles among students are differ across different streams and courses (Bakon et al., 2016; Demirkan, 2016). Perhaps, the different in learning style preference could be due to individually unique ways of educational activity depending on its own cluster.

The Relationship between Learning Styles and Students' Academic Performance This section reports and discusses the findings of the study which relate to the second research objectives, which is to determine the relationship between students' learning styles and their academic performance. The learning styles under consideration of this study are of Visual (V), Aural (A), Read/Write (R), and Kinesthetic (K). Table 5 shows the summary results of the standard multiple regressions analysis on the relationship between students' learning styles and their academic performance in the private university in Selangor.

Table 5: The Relationship between Learning Style and Students' Academic Performance

\begin{tabular}{lcccc}
\hline & Hypotheses & $\begin{array}{c}\text { Std. Beta } \\
\text { Coefficient }\end{array}$ & $\boldsymbol{t}$-statistic & $\boldsymbol{p}$ value \\
\hline Intercept & & & 18.622 & $.000^{* * *}$ \\
Visual (V) & $\mathrm{H}_{4 \mathrm{~A}}$ & $\mathbf{0 . 2 0 6}$ & $\mathbf{2 . 3 4 1}$ & $\mathbf{. 0 0 9}^{* * * *}$ \\
Aural (A) & $\mathrm{H}_{4 \mathrm{~B}}$ & -0.072 & -1.297 & .195 \\
Read/Write (R) & $\mathrm{H}_{4 \mathrm{C}}$ & -0.040 & -0.716 & .474 \\
Kinesthetic (K) & $\mathrm{H}_{4 \mathrm{D}}$ & $\mathbf{0 . 3 0 7}$ & $\mathbf{4 . 1 2 6}$ & $\mathbf{. 0 0 2}^{* * * *}$ \\
& & & & \\
\hline Model Summary: & & & & \\
$\quad \mathrm{R}^{2}$ value & & & & \\
\hline Anova Results: & & & & \\
$\quad$ F-value & & & & \\
$\quad$ Sig. value & & & & \\
$\quad$ Obs. & & & & \\
\hline
\end{tabular}

Note: Association is significant at ${ }^{* * *} 1 \%$ level, ${ }^{* *} 5 \%$ level, respectively, using two-tailed tests. 
Table 5 reveals that the regression model $(F(4,433)=18.839, p$ value $<.05)$ is significant at the confidence level of $99 \%$ level, and the overall fit of the model is moderate with $\mathrm{R}^{2}$ value of $36.1 \%$ of the variation in the students' academic performance. Approximately, $36.1 \%$ of the total variability in the academic performance of students is accounted for by the predictor variables collectively in the model. Based on the results shown in the Table 5 above, only two learning style preference, i.e. Visual (V) and Kinesthetic (K) are positively and significantly influence students' academic performance in the private university in Selangor and both are significant at $1 \%$ level. The finding of this study is consistent with a result found by Dobson (2010). He suggested that a solid Kinesthetic (K) learning style had a significant positive relationship with performance in physiology courses among a sample of 64 students. Further, the results show that Aural (A) and Read/Write (R) did not significantly influence students' academic performance.

In predicting the dominant learning style preference in influencing the academic performance of undergraduate students at the private university in Selangor, this study refers to the Beta Value under Standardised Coefficient. Table 5 reveals that Kinesthetic (K) learning style is the most dominant factor as it has the highest influence towards students' academic performance $(\beta=0.307)$ and it is followed by Visual (V) learning style $(\beta=0.206)$. Meanwhile, Aural (A) $(\beta=-0.072)$ and $\operatorname{Read} /$ Write $(\mathrm{R})(\beta=-0.040)$ learning styles has the least influence on the students' academic performance as both learning style did not significant.

\section{Conclusion}

The finding of this study suggests that all undergraduate students were unimodal learners and none of them was a bimodal learner. The learner type with the greatest number of students was the Kinesthetic $(\mathrm{K})$ type of learning style. Majority of the respondents of high achievers are preferred Kinesthetic $(\mathrm{K})$ learning style while Read/Write $(\mathrm{R})$ learning style are more practiced by students with low achievement. Further, male students are more preferred Kinesthetic (K) learning style, but female students had a higher preference for Visual (V) learning style. Besides, students in the social science cluster are more preferred an Aural (A) learning style as compared to the students in pure science cluster which are more preferred Read/Write $(\mathrm{R})$ learning style. These results indicate that there is no fixed pattern in the preferred learning styles of students in the private university in Selangor.

This study also reveals that Visual (V) and Kinesthetic (K) learning style preferences are positively and significantly influence students' academic performance in the private university in Selangor. Overall, the findings of this study could be related to the "Meshing Hypothesis." The "Meshing Hypothesis" states that the learning outcomes could be highly achieved if learning was matched with predominant learning style of the learner (Sankey et al., 2012). However, Pashler et al. (2008) argued that the Meshing Theory was not necessarily correct because the undergraduate students were not always exposed to multiple types of learning styles for the same subject. Different subjects required different kinds of learning styles and instructions to optimally potentiate and benefit the students (Pashler et al., 2008).

Findings of this study implicate that in practice, lecturers in the field cannot use a one size-fitall curriculum for social science and pure science students from different backgrounds. Mixed teaching and learning activities will enhance the learning experience of students from a diverse background, and these activities have to be tailor-made for individual courses and institutions. Given that the majority of students were unimodal learners, it is also indicated that the lecturers 
may make efforts in the future to encourage a wider variety of learning methods. Multi-sensory learning may help improve information recall.

\section{Limitations \& Recommendation of Future Research}

Some limitations of this study should be acknowledged and directions for future studies should also be suggested. First, this study is limited to a single university, with a limited, yet diverse student's population. It is unlikely for the results of the statistical analysis to be attributed to chance, but this does not necessarily imply that they are valid outside this university or that they can be generalized to other settings. Hence, to get a better picture for future studies, it can include more universities in the research.

Another limitation of this study, and any study using the VARK questionnaire, is that it does not account for confounding factors such as socioeconomic status, race, culture, etc. However, the relatively homogenous population surveyed in this study is likely to be less affected by these factors. A strong point of the VARK questionnaire is that its questions and options are drawn from real-life situations and respondents identify with the results that they receive-they affirm the face validity of the tool. However, although self-perceptions are not always reliable, these data support the validity of the VARK questionnaire.

\section{References}

Alghasham, A. A. (2012). Effect of students' learning styles on classroom performance in problem-based learning. Medical Teacher, 34(S1), S14-S19.

Almigbal, T. H. (2015). Relationship between the learning style preferences of medical students and academic achievement. Saudi Medical Journal, 36(3), 349.

Al-Saud, L. M. S. (2013). Learning style preferences of first-year dental students at King Saud University in Riyadh, Saudi Arabia: Influence of gender and GPA. Journal of Dental Education, 77(10), 1371-1378.

Ao X. (2014). A comparative study on the students' concepts on learning. International Journal Research on Students Education, 3, 41-48.

Aripin, R., Mahmood, Z., Rohaizad, R., Yeop, U., \& Anuar, M. (2008). Students' learning styles and academic performance. Proceedings of the Annual SAS Malaysia Forum; 2008 July 15; Kuala Lumpur, Malaysia.

Bakon, S., Christensen, M., \& Craft, J. (2016). An exploration of the relationship between nursing students' learning style and success in bio-science education: An integrative review of the literature. Educational Healthcare, 3(2), 32-54.

Bertolami, C. N. (2001). Rationalizing the dental curriculum in light of current disease prevalence and patient demand for treatment: form vs. content. Journal of Dentist Education, 65(8), 725-735.

Brew, C. R. (2002). Kolb's learning style instrument: Sensitive to gender. Educational and Psychological Measurement, 62, 373-390.

Cavanagh, S. J., \& Coffin, D. A. (1994). Matching instructional preference and teaching styles: a review of the literature. Nurse Education Today, 14(2), 106-110.

Choudhary, R., Dullo, P. \& Tandon, R. V. (2011). Gender differences in learning style preferences of first year medical students. Pakistan Journal of Physiology, 7, 42-45.

Chun, M. (2014). A study on college students' use intention of internet learning resources in Chongqing. Asian Social Science, 10(3), 70-89.

Demirkan, H. (2016). An inquiry into the learning-style and knowledge-building preferences of interior architecture students. Design Studies, 44, 28-51.

Derkach, T. \& Starova, T. (2017). Preferred learning styles of students of natural field of study. Science and Education, 6, 51-56. doi: 10.24195/2414-4665-2017-6-8. 
Derkach, T. (2018). Preferred learning styles of students majoring in chemistry, pharmacy, technology and design. Advanced Education, 5, 55-61.

Dobson, J. L. (2010). A comparison between learning style preferences and sex, status, and course performance. Advances in Physiology Education, 34(4), 197-204.

Felder, R. M. \& Spurlin, J. (2005). Applications, reliability and validity of the index of learning styles. International Journal of Engineering Education, 21(1), 103-112.

Felder, R. M., Felder, G. N., \& Dietz, E. J. (2012). The effects of personality type on engineering student performance and attitudes. Journal of Engineering Education, 91(1), 3-17.

Fleming N. (2007). VARK: a guide to learning styles. Available from: http://www.varklearn.com/english/ index.asp.

Fleming, N. D. \& Mills, C. (1992). Not another inventory, rather a catalyst for reflection. To Improve the Academy, 11, 137-155.

Fleming, N. D. (1995). I'm different; not dumb: Modes of presentation (VARK) in the tertiary classroom. In: Research and Development in Higher Education, edited by Zelmer A. Canberra, Australia: Proceedings of the 1995 Annual Conference of the Higher Education and Research Development Society of Australia, 1995, p. 303-318.

Fleming, N. D. (2005). Teaching and Learning Styles: VARK Strategies. (2 ${ }^{\text {nd }}$ Ed.). Christchurch, New Zealand: The Digital Print and Copy Center.

Fleming, N. D. (2015). VARK: A Guide to Learning Styles. Available: http://vark-learn.com/ (Access time August 2017)

Heikkilä, A., \& Lonka, K. (2006). Studying in higher education: Students' approaches to learning, self-regulation, and cognitive strategies. Studies in Higher Education, 31, 99117. doi: $10.1080 / 03075070500392433$.

Hosford, C. C. \& Siders, W. A. (2010). Felder-Soloman's index of learning styles: Internal consistency, temporal stability, and factor structure. Teacher Learning Medical, 22(4), 298-303.

Hur, Y., \& Kim, S. (2017). Different outcomes of active and reflective students in problembased learning. Medical Teacher, 29(1), 18-21.

James, W. B., \& Gardner, D. L. (1995). Learning styles: Implications for distance learning. New directions for Adult and Continuing Education, 67, 19-31.

Kharb, P., Samanta, P. P., Jindal, M., \& Singh, V. (2013). The learning styles and the preferred teaching-learning strategies of first year medical students. Journal of Clinical and Diagnostic Research, 7(6), 1089-1092.

Krejcie, R. V., \& Morgan, D. W. (1970). Determining sample size for research activities. Educational and Psychology Measurement, 30(3), 76-91.

Leite, W. L., Svinicki, M., \& Shi, Y. (2010). Attempted validation of the scores of the VARK: learning styles inventory with multi-trait multi-method confirmatory factor analysis models. Educational Psychology Measure, 70, 323-339.

Liew, S. C., Sidhu, J., \& Barua, A. (2015). The relationship between learning preferences (styles and approaches) and learning outcomes among pre-clinical undergraduate medical students. BMC Medical Education, 15(1), 44.

Marriott, P. (2002). A longitudinal study of undergraduate accounting students' learning style preferences at two UK universities. Accounting Education, 11(1), 43-62.

May, W., Chung, E. K., Elliott, D., \& Fisher, D. (2012). The relationship between medical students' learning approaches and performance on a summative high-stakes clinical performance examination. Medical Teacher, 34, e236-e241. doi: $10.3109 / 0142159 x .2012 .652995$. 
Nuzhat, A., Salem, R. O., Al Hamdan, N. \& Ashour, N. (2013). Gender differences in learning styles and academic performance of medical students in Saudi Arabia. Medicine Teaching, 35(S1), S78-82.

Pashler, H., McDaniel, M., Rohrer, D., \& Bjork, R. (2008). Learning styles: Concepts and evidence. Psychological Science in the Public Interest, 9(3), 105-119.

Prasad, J. J., Showler, M. B., Ryan, A. M., Schmitt, N., \& Nye, C. D. (2017). When belief precedes being: How attitudes and motivation before matriculation lead to fit and academic performance. Journal of Vocational Behavior, 100, 27-42.

Raja, T. A. R., \& Priyadharsini, R. (2018). Medical Education/Original Article Motivating but Not Labelling the Students: A Qualitative Study on the Preferences of Learning Styles Among Undergraduate Medical Students. Indian Journal of Physiology and Pharmacology, 62(2), 267-273.

Reid, J. M. (1995). Learning Styles in the ESL/EFL Classroom. Heinle \& Heinle Publishers.

Richardson, J. T. E. (2013). Approaches to studying across the adult life span: Evidence from distance education. Learning and Individual differences, 26, 74-80. doi: 10.1016/j.lindif.2013.04.012.

Romanelli, F., Bird, F. \& Ryan, M. (2009). Learning styles: A review of theory, application, and best practices. American Journal of Pharmaceutical Education, 73(1), 9-21. doi: 10.5688/aj730109

Samarakoon, L., Fernando, T., Rodrigo, C., \& Rajapakse, S. (2013). Learning styles and approaches to learning among medical undergraduates and postgraduates. BMC Medical Education, 13(1), 1-14.

Sandmire, D. A., Vroman, K. G., \& Sanders, R. (2000). The influence of learning styles on collaborative performances of allied health students in a clinical exercise. Journal of Allied Health, 29(3), 143-149.

Sankey, M., Birch, D., \& Gardiner, M. (2012). The impact of multiple representations of content using multimedia on learning outcomes across learning styles and modal preferences. International Journal of Education and Development using ICT, 7(3), 1835.

Sarabi-Asiabar, A., Jafari, M., Sadeghifar, J., Tofighi, S., Zaboli, R., Peyman, H., ... \& Shams, L. (2015). The relationship between learning style preferences and gender, educational major and status in first year medical students: A survey study from iran. Iranian Red Crescent Medical Journal, 17(1), 182-196.

Shenoy, N., \& Shenoy, A. (2013). The perceptual preferences in learning among dental students in clinical subjects. Journal of Clinical and Diagnostic Research: JCDR, 7(8), 1683.

Tariq, S., Khan, M. A., Afzal, S., Shahzad, S. R., Hamza, M., Khan, H. A., ... \& Puri, B. I. (2016). Association between academic learning strategies and annual examination results among medical students of King Edward Medical University. Annals of King Edward Medical University, 22(2), 124-134.

Wilson, K. \& Narayan, A. (2014). Relationships among individual task self-efficacy selfregulated learning strategy use and academic performance in a computer-supported collaborative learning environment. Educational Psychology, 36(2), 236-253. Doi: $10.1080 / 01443410.2014 .926312$

Yaroshenko, O. G. \& Derkach, T. M. (2012). Comparative analysis of learning styles for students of different specialties. Pedagogika i Psykhologia, 1, 43-47. 